Journal of Agricultural Sciences
(Tarim Bilimleri Dergisi)

\title{
Transplanting and Seed Hydro-priming Affects Yield, Water Use Efficiency, and Grain Quality of Maize Cultivars under Delayed Planting
}

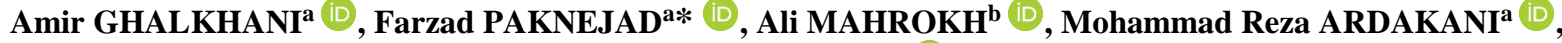 \\ Farid GOLZARDI ${ }^{b}$ iD \\ ${ }^{a}$ Department of Agronomy, Karaj Branch, Islamic Azad University, Karaj, IRAN \\ ${ }^{b_{S e e d}}$ and Plant Improvement Institute, Agricultural Research, Education and Extension Organization (AREEO), Karaj, IRAN
}

ARTICLE INFO

Research Article

Corresponding Author: Farzad Paknejad, E-mail: farzadpaknejad@yahoo.com

Received: 18 September 2021 / Revised: 11 December 2021 / Accepted: 11 December 2021 / Online: 15 October 2022

Cite this article

GHALKHANI A, PAKNEJAD F, MAHROKH, ARKADANI R Z, GOLZARDI F (2022). Transplanting and Seed Hydro-priming Affects Yield, Water Use Efficiency, and Grain Quality of Maize Cultivars under Delayed Planting. Journal of Agricultural Sciences (Tarim Bilimleri Dergisi), 28(4):740-750. DOI: 10.15832/ankutbd.995878

\section{ABSTRACT}

To evaluate the effect of planting method (PM), planting date (PD), and cultivar $(\mathrm{CV})$ on the grain and herbage yield, irrigation water use efficiency for herbage (IWUEH) and grain (IWUEG), and grain quality of maize, a two-year field study was conducted at the Research Farm of Seed and Plant Improvement Institute, Karaj, Iran, during the 2017 and 2018 growing seasons. The experiment was arranged as split-plot factorial with three planting dates, including PD1 (July $1^{\text {st }}$ ), PD2 (July $\left.11^{\text {th }}\right)$, and PD3 (July $\left.23^{\text {rd }}\right)$ as main plots. Three planting methods, including direct seeding (DS), seed hydro-priming (HP), and transplanting (TP), were factorially combined with two maize cultivars (S.C.704 and S.C.260) as sub-plots. The highest herbage and grain yields (76685 and $7369 \mathrm{~kg} \mathrm{ha}^{-1}$, respectively) and the maximum IWUE for herbage and grain production (13.1 and $1.21 \mathrm{~kg} \mathrm{~m}^{-3}$, respectively) were found in the TP. The CV S.C.704 obtained a higher grain yield (GY) on PD1 than that of S.C.260, but as planting was delayed, the GY of S.C.704 was affected more negatively in both years. Delay planting enhanced IWUEH, but not IWUEG. The highest IWUEG was obtained from TP on each PD. The CV S.C.260 in delay planting resulted in better IWUEG in both years. The highest and lowest contents of crude protein, starch, ash, crude fiber, and oil were obtained from hydro-primed and transplanted maize, respectively. In conclusion, the yield in the transplanting method had superiority over DS and HP. Also, HP was found to be the optimal PM to enhance the grain quality of maize in delayed planting. Furthermore, selecting S.C.260 as a high-yielding hybrid on delayed planting is suggested.

Keywords: Planting method, Planting date, Zea mays L, Crude protein, Semi-arid region

\section{Introduction}

Maize (Zea mays L.) is one of the main cultivated cereals in the world (FAO 2019). As the consumption of maize increases due to its vital role in human and animal diet, the countries' demand for grain maize has grown fast (Loy \& Lundy 2019; Ünay et al. 2021). On the other hand, the production of crops such as maize declined remarkably in arid and semi-arid regions worldwide (Golzardi et al. 2017). The high percent of grain maize cultivated in the second cropping; nevertheless, water shortage and short growing season in the semi-arid regions are the main problems of farmers to produce high-yield maize (Khalily et al. 2010). The shortage of growing season in the second cropping causes the maize to be harvested too early with high moisture content, which reduces the maize grain yield (GY) and consequently causes economic losses for the farmers in storage conditions (Moradi et al. 2013). Indeed, delayed planting will expose the maize to different conditions of temperature, water availability, photoperiod, and solar radiation. Several studies reported that delayed planting of maize significantly reduced the GY and herbage yield (HY) as well as irrigation water use efficiency (IWUE) (Srivastava et al. 2018; Cao et al. 2019).

Germination is particularly important for determining the final plant density. Delayed cultivation of maize reduces its GY by postponing the germination and growth stages (Long et al. 2017). Choosing a suitable planting method (PM) that could lead to the early maturity of maize in delayed planting might result in lower maize yield losses. Grain maize producers require more information on how PM and planting date (PD) affect the yield of grain maize in the delayed sowing.

Transplanting (TP) is a planting strategy used for higher crop yield, especially when the condition is not suitable for direct seeding (DS). Fanadzo et al. (2009) reported that transplanting can be used as a planting method to compensate for yield loss in delayed planting of maize by improving its establishment and germination and reducing the growth period and flowering time. Furthermore, another planting method that can improve the yield of maize is seed hydro-priming (HP). This method is based on 
controlled irrigation technology, and hydro-primed seeds go through the first (physical absorption of water) and second (initiation of biological processes and carbohydrate hydrolysis) stages of germination, though failing to pass the third stage (carbohydrate intake by the embryo and rootlet growth) (Nazari et al. 2017). Rehman et al. (2015) reported that hydro-priming as an important physiological method could accelerate and boost the strength of germination processes. Furthermore, previous studies revealed that transplanted and hydro-primed maize could use available water more efficiently (San Miguel-Chávez \& Larqué Saavedra 1996; Rockström et al. 2007).

It was hypothesized that transplanting and hydro-priming increased maize grain yield and quality and IWUE compared to direct seeding in delayed planting. Recently, due to the increasing need for more grain maize production in arid and semi-arid regions, determining the optimum planting method and planting date to improve the IWUE, quantity, and quality of grain maize in delayed planting has received considerable critical attention. Although many studies have investigated the effect of transplanting and hydro-priming on grain and herbage yield, the impacts of these planting methods on IWUE and grain quality under delayed planting are not well documented. Furthermore, previous reports did not compare the transplanting and hydropriming methods regarding their effects on grain maize yield, quality, and IWUE. Therefore, the present study was carried out to evaluate the impact of transplanting and hydro-priming on the IWUE and grain quality besides grain yield of early- and latematuring cultivars of maize to determine the most suitable planting method in delayed planting for a semi-arid environment.

\section{Material and Methods}

This study was carried out at the Research Farm of Seed and Plant Improvement Institute, Karaj, Iran ( $35^{\circ} 47^{\prime} \mathrm{N}, 50^{\circ} 54^{\prime} \mathrm{E}, 1250$ m. a.s.1.), during the 2017 and 2018 cropping seasons. The climate of this region is characterized as semi-arid, with a long-term average annual rainfall of $251 \mathrm{~mm}$ and annual evaporation of $2184 \mathrm{~mm}$. The long-term average air temperature was $13.5^{\circ} \mathrm{C}$, and the average soil temperature was $14.5^{\circ} \mathrm{C}$ in Karaj. The meteorological characteristics of the two years of the study sites are presented in Table 1. The physical and chemical characteristics of the soil of the study location are shown in Table 2.

Table 1- The monthly meteorological data of experimental sites during 2017 and 2018 growing seasons

\begin{tabular}{|c|c|c|c|c|c|c|c|c|}
\hline Year & Month & $\begin{array}{l}\text { Mean soil } \\
\text { temp }\left({ }^{\circ} \mathrm{C}\right)\end{array}$ & $\begin{array}{l}\operatorname{Max} \quad \text { air } \\
\operatorname{temp}\left({ }^{\circ} \mathrm{C}\right)\end{array}$ & $\begin{array}{l}\text { Min } \quad \text { air } \\
\text { temp }\left({ }^{\circ} \mathrm{C}\right)\end{array}$ & $\begin{array}{l}\text { Mean air } \\
\text { temp }\left({ }^{\circ} \mathrm{C}\right)\end{array}$ & $\begin{array}{l}\text { Evaporation } \\
(\mathrm{mm})\end{array}$ & $\begin{array}{l}\text { Precipitation } \\
(\mathrm{mm})\end{array}$ & $\begin{array}{l}\text { Relative } \\
\text { Humidity }(\%)\end{array}$ \\
\hline \multirow{6}{*}{2017} & June & 13.41 & 34.16 & 17.6 & 26.08 & 338.6 & 0.00 & 32.30 \\
\hline & July & 16.65 & 36.41 & 20.29 & 28.88 & 367.8 & 0.41 & 29.54 \\
\hline & August & 16.26 & 34.88 & 19.35 & 27.44 & 355.5 & 0.00 & 32.57 \\
\hline & September & 12.53 & 31.59 & 15.92 & 23.72 & 267.6 & 0.00 & 34.37 \\
\hline & October & 7.00 & 23.87 & 10.59 & 17.02 & 175.5 & 4.80 & 38.55 \\
\hline & November & 2.10 & 17.26 & 6.148 & 11.53 & 89.3 & 0.64 & 43.48 \\
\hline \multirow{6}{*}{2018} & June & 15.53 & 33.81 & 17.35 & 25.58 & 334.3 & 7.23 & 37.27 \\
\hline & July & 21.16 & 38.87 & 23.31 & 31.91 & 471.8 & 0.00 & 22.06 \\
\hline & August & 17.87 & 36.18 & 20.08 & 28.41 & 425.6 & 0.00 & 33.73 \\
\hline & September & 13.70 & 31.56 & 16.79 & 23.99 & 266.1 & 0.81 & 34.9 \\
\hline & October & 9.03 & 22.62 & 11.07 & 16.62 & 137.6 & 29.12 & 52.71 \\
\hline & November & 3.80 & 13.24 & 5.45 & 9.06 & 70.3 & 65.91 & 73.17 \\
\hline
\end{tabular}

Temp: temperature; Max: maximum; Min: minimum.

Table 2- Physicochemical properties of the soil $(0-30 \mathrm{~cm})$ at the experimental site during 2017 and 2018 growing seasons

\begin{tabular}{|c|c|c|c|c|c|c|c|c|c|c|}
\hline Year & Soil texture & $\begin{array}{l}\text { Clay } \\
(\%)\end{array}$ & $\begin{array}{l}\text { Silt } \\
(\%)\end{array}$ & $\begin{array}{l}\text { Sand } \\
(\%)\end{array}$ & $\begin{array}{l}N \\
(\%) \\
\end{array}$ & $\begin{array}{l}P \\
\left(m g k g^{-1}\right)\end{array}$ & $\begin{array}{l}K \\
\left(m g k g^{-1}\right)\end{array}$ & $\begin{array}{l}O M \\
(\%) \\
\end{array}$ & $\begin{array}{l}E C \\
(d s / m)\end{array}$ & $p H$ \\
\hline 2017 & Clay loam & 28 & 49 & 23 & 0.06 & 12.0 & 256 & 0.55 & 2.21 & 7.22 \\
\hline 2018 & Clay loam & 29 & 48 & 23 & 0.07 & 12.2 & 254 & 0.57 & 2.20 & 7.21 \\
\hline
\end{tabular}

OM: organic matter; EC: electrical conductivity

A split-plot factorial design was set up based on a randomized complete block design with three replications. The planting date at three levels (July 1, 11, 23) was allocated to the main plots, and factorial of planting methods at three levels (HP, TP and DS) and cultivars (S.C.704, S.C.260) were allocated in the subplots. Each subplot consists of 3-rows spaced $75 \mathrm{~cm}$ apart and measuring $6 \mathrm{~m}$ long. Spaces between plants in the rows were $18 \mathrm{~cm}$ for S.C.704 (planting density of 7.5 plants $\mathrm{m}^{-2}$ ) and $16 \mathrm{~cm}$ for S.C.260 (planting density of 8.3 plants $\mathrm{m}^{2}$ ).

Seedbed prepared by plowing, disc, and leveling. Chemical fertilizers were applied based on soil analysis (Table 2) and the nutritional needs of maize. A total of $250 \mathrm{~kg} \mathrm{ha}^{-1} \mathrm{di}$-ammonium phosphate (DAP) and $200 \mathrm{~kg} \mathrm{ha}^{-1}$ urea were added to the soil before cultivation. In addition, when the plants reached the stage of 6-8 leaves, urea was applied as topdressing with a rate of $200 \mathrm{~kg} \mathrm{ha}^{-1}$. 
Seeds for TP were sown in a tray with holes full of soil (60\% soil, $20 \%$ animal manure, $20 \%$ sand). Crops were fertilized with a dose of fertilizer $\left(20: 20: 20 ; \mathrm{N}: \mathrm{P}_{2} \mathrm{O}_{5}: \mathrm{K}_{2} \mathrm{O} \mathrm{kg} \mathrm{ha}{ }^{-1}\right)+$ humic acid, two times, first after the emergence of primary leaves $(\mathrm{BBCH}=12)$, then one week later. After attaining the age of three weeks (2-3 leaves stage), seedlings were uprooted manually and transplanted to the main field on the same day. The hydro-primed seeds were laid out in distilled water, and the surfaces of seeds were dried at optimum temperature and, finally, were planted in the PD according to experimental treatments (Rashid et al. 2006).

The irrigation system was drip irrigation. For determining irrigation water volume, sampled from the plot soil up to deep root development, and determined soil moisture percentage. Irrigation water volume was calculated by Penman-Monteith (Allen et al. 1998). The volume of water consumed in each PD is shown separately in Table 3. It should be noted that the amount of water used to produce seedlings has also been added to the amount of water used in the field. Also, for each treatment, the time interval between planting and harvesting date is reported in Table 4. The growing degree days (GDD) was calculated using the equation 1 , where $\mathrm{T}_{\max }, \mathrm{T}_{\min }$, and $\mathrm{T}_{\text {base }}$ are the maximum temperature, minimum temperature, and $10{ }^{\circ} \mathrm{C}$ base temperature, respectively (McMaster \& Wilhelm 1997):

$$
G D D=\sum_{0}^{n}\left[\frac{T_{\max }+T_{\min }}{2}\right]-\boldsymbol{T}_{\text {base }}
$$

Table 3- Total volume of irrigation water used $\left(\mathrm{m}^{3} \mathrm{ha}^{-1}\right)$ in each treatment during2017 and 2018 growing seasons

\begin{tabular}{|c|c|c|c|c|c|c|c|}
\hline \multirow{2}{*}{ Planting method } & \multirow{2}{*}{ Cultivar } & \multicolumn{3}{|r|}{2017} & \multicolumn{3}{|r|}{2018} \\
\hline & & July 1 & July 11 & July 23 & July 1 & July 11 & July 23 \\
\hline \multirow{2}{*}{ Direct seeding } & 260 & 6459 & 5672 & 4826 & 6928 & 6012 & 5261 \\
\hline & 704 & 6459 & 5672 & 4826 & 6928 & 6012 & 5261 \\
\hline \multirow{2}{*}{ Hydro-priming } & 260 & 6459.05 & 5672.05 & 4826.05 & 6928.05 & 6012.05 & 5261.05 \\
\hline & 704 & 6459.05 & 5672.05 & 4826.05 & 6928.05 & 6012.05 & 5261.05 \\
\hline \multirow{2}{*}{ Transplanting } & 260 & 6480 & 5694 & 4850 & 6950 & 6035 & 5285 \\
\hline & 704 & 6480 & 5694 & 4850 & 6950 & 6035 & 5285 \\
\hline
\end{tabular}

Table 4- Growing degree days and days from planting to harvest in different treatments during 2017 and 2018 growing seasons

\begin{tabular}{|c|c|c|c|c|c|c|c|c|}
\hline \multirow{2}{*}{ Year } & \multirow{2}{*}{ Planting method } & \multirow{2}{*}{ Cultivar } & \multicolumn{3}{|c|}{ July 1} & \multicolumn{2}{|l|}{ July 11} & July 23 \\
\hline & & & $G D D$ & $D A P$ & $G D D$ & DAP & $G D D$ & $D A P$ \\
\hline \multirow{6}{*}{2017} & \multirow{2}{*}{ Direct seeding } & 260 & 1407.8 & 106 & 1333.3 & 108 & 1234 & 104 \\
\hline & & 704 & 1534.5 & 122 & 1423.6 & 119 & 1246.9 & 106 \\
\hline & \multirow{2}{*}{ Hydro-priming } & 260 & 1448.6 & 113 & 1306.9 & 105 & 1234 & 104 \\
\hline & & 704 & 1511.6 & 120 & 1423.6 & 119 & 1246.9 & 106 \\
\hline & \multirow{2}{*}{ Transplanting } & 260 & 1245.3 & 86 & 1241 & 94 & 1249.3 & 91 \\
\hline & & 704 & 1448.6 & 113 & 1380.3 & 112 & 1246.9 & 106 \\
\hline \multirow{6}{*}{2018} & \multirow{2}{*}{ Direct seeding } & 260 & 1543.9 & 112 & 1457.8 & 118 & 1252.1 & 106 \\
\hline & & 704 & 1583.4 & 117 & 1457.8 & 118 & 1252.1 & 106 \\
\hline & \multirow{2}{*}{ Hydro-priming } & 260 & 1530.6 & 110 & 1457.8 & 118 & 1252.1 & 106 \\
\hline & & 704 & 1615.1 & 125 & 1457.8 & 118 & 1252.1 & 106 \\
\hline & \multirow{2}{*}{ Transplanting } & 260 & 1452 & 98 & 1396.2 & 104 & 1252.1 & 106 \\
\hline & & 704 & 1599.7 & 119 & 1457.8 & 118 & 1252.1 & 106 \\
\hline
\end{tabular}

GDD: growing degree days; DAP: days after planting.

For yield determination, plants were harvested from an area of $3.75 \mathrm{~m}^{2}$ in each plot. The herbage yield was measured at the dough stage, and grain yield was measured at the physiological maturity stage. The irrigation water use efficiency was calculated as yield divided by irrigation water (Golzardi et al. 2017). One kilogram of grain was randomly selected from every treatment to determine grain quality, then samples were milled, and crude fiber (CF), ash, water-soluble carbohydrates (WSC), crude protein (CP), starch, oil, and digestible dry matter (DDM) were measured by NIR (near infra-red) device (DICKEY-gun model) (Siesler et al. 2002; Baghdadi et al. 2017).

Homogeneity of experimental errors in two years was tested following Bartlett's test (Bartlett 1937), and data were imposed to combine analysis of variance. The statistical model was $Y_{i j k l}=\mu+R_{l}+A_{i}+E_{i l}+B_{j}+(A B)_{i j}+C_{k}+(A C)_{i k}+(B C)_{j k}+(A B C)_{i j k}+$ $E_{i j k l}$, where $\mu, R_{1}, A_{i}, E_{i l}, B_{j}, C_{k}$, and $E_{i j k l}$ were the total mean, the effects of the block, planting date, the error of main factor $\left(E_{a}\right)$, 
planting methods, cultivar, and the error of sub-factors $\left(E_{b}\right)$, respectively. Year and block were considered as random effects, whereas the planting date, planting methods, and cultivar were deemed to be fixed effects. Statistical analysis was performed using SAS software version 9.4, and the means were compared by Duncan's multiple range test $(\mathrm{P}<0.05)$.

\section{Results and Discussion}

\subsection{Herbage yield}

The results indicated that HY was influenced by PD, and shortening the growing season could significantly reduce it (Table 5). The highest HY was recorded on PD1 (74407 kg ha'-1), and the lowest HY was recorded on PD3 (67261 kg ha ${ }^{-1}$ ) (Table 6). Delayed planting from PD1 to PD2 and PD3 decreased the available GDD by about 174.5 and 364.1, respectively (Table 4), and consequently reduced the HY by $5 \%$ and $10 \%$ (Table 6 ).

Table 5- P-Values obtained from ANOVA for the effect of planting date (July 1, July 11, and July 23), planting method (hydro-priming, transplanting, and direct seeding) and cultivar (S.C. 704 and S.C.260) on yield and irrigation water use efficiency of maize

\begin{tabular}{llllll}
\hline Source of variation & $\boldsymbol{d} \boldsymbol{f}$ & Herbage yield & IWUE $_{\boldsymbol{H}}$ & Grain yield & IWUE $_{\boldsymbol{G}}$ \\
\hline Year $(\mathbf{Y})$ & 1 & 0.1643 & 0.3335 & 0.6986 & 0.9097 \\
Rep (Year) & 4 & 0.4096 & 0.4307 & 0.7571 & 0.7968 \\
$\mathbf{P l a n t i n g}$ Date $(\mathbf{P D})$ & 2 & 0.0277 & 0.027 & 0.0077 & 0.0084 \\
$\mathbf{Y} \times \mathbf{P D}$ & 2 & 0.7243 & 0.9944 & 0.4503 & 0.5692 \\
$\mathbf{R e p}(\mathbf{Y} \times \mathbf{P D})$ & 8 & 0.7252 & 0.6085 & 0.1532 & 0.2320 \\
$\mathbf{P l a n t i n g}$ Method $(\mathbf{P M})$ & 2 & 0.0278 & 0.0427 & 0.0378 & 0.0420 \\
$\mathbf{P D} \times \mathbf{P M}$ & 4 & 0.1195 & 0.0628 & 0.0366 & 0.0466 \\
$\mathbf{Y} \times \mathbf{P M}$ & 2 & 0.2603 & 0.2451 & 0.5472 & 0.5226 \\
$\mathbf{Y} \times \mathbf{P D} \times \mathbf{P M}$ & 4 & 0.2678 & 0.2915 & 0.6745 & 0.6283 \\
$\mathbf{C u l t i v a r}(\mathbf{C V})$ & 1 & 0.0534 & 0.0767 & 0.4900 & 0.3335 \\
$\mathbf{Y} \times \mathbf{C V}$ & 1 & 0.4004 & 0.2525 & 0.5246 & 0.5772 \\
$\mathbf{P D} \times \mathbf{C V}$ & 2 & 0.2297 & 0.8420 & 0.1302 & 0.1298 \\
$\mathbf{Y} \times \mathbf{P D} \times \mathbf{C V}$ & 2 & 0.2610 & 0.1976 & 0.0441 & 0.0348 \\
$\mathbf{P M} \times \mathbf{C V}$ & 2 & 0.0015 & 0.0023 & 0.2503 & 0.2086 \\
$\mathbf{Y} \times \mathbf{P M} \times \mathbf{C V}$ & 2 & 0.9603 & 0.9338 & 0.2295 & 0.2434 \\
$\mathbf{P D} \times \mathbf{P M} \times \mathbf{C V}$ & 4 & 0.1538 & 0.0862 & 0.1911 & 0.1584 \\
$\mathbf{Y} \times \mathbf{P D} \times \mathbf{P M} \times \mathbf{C V}$ & 4 & 0.9923 & 0.992 & 0.4438 & 0.483 \\
\hline
\end{tabular}

df: degree of freedom; IWUE $\mathrm{H}_{\mathrm{H}}$ irrigation water use efficiency for herbage production; IWUE $_{\mathrm{G}}$ : irrigation water use efficiency for grain production

Table 6- The effect of year, planting date, planting method and cultivar on yield, irrigation water use efficiency

\begin{tabular}{|c|c|c|c|c|c|}
\hline \multirow{2}{*}{\multicolumn{2}{|c|}{ Experimental Factors }} & Herbage yield & Grain yield & $I W U E_{H}$ & $I W U E_{G}$ \\
\hline & & \multicolumn{2}{|l|}{$\left(\boldsymbol{k g h a ^ { - 1 } )}\right.$} & \multicolumn{2}{|c|}{$\left(\mathrm{kg} \mathrm{m}^{-3}\right)$} \\
\hline \multirow{2}{*}{ Year } & 2017 & $69505 \mathrm{a}$ & $6775 a$ & $12.4 \mathrm{a}$ & $1.16 \mathrm{a}$ \\
\hline & 2018 & $72318 \mathrm{a}$ & $6565 \mathrm{a}$ & $12.0 \mathrm{a}$ & $1.04 \mathrm{a}$ \\
\hline \multirow{3}{*}{$\begin{array}{l}\text { Planting } \\
\text { Date }\end{array}$} & July 01 & $74407 a$ & $8890 \mathrm{a}$ & $11.1 \mathrm{~b}$ & $1.32 \mathrm{a}$ \\
\hline & July 11 & $71067 \mathrm{a}$ & $8004 a$ & $12.2 b$ & $1.37 \mathrm{a}$ \\
\hline & July 23 & $67261 b$ & $3115 b$ & $13.3 \mathrm{a}$ & $0.62 b$ \\
\hline \multirow{3}{*}{$\begin{array}{l}\text { Planting } \\
\text { Method }\end{array}$} & DS & $66741 b$ & $6189 b$ & $11.4 \mathrm{~b}$ & $1.02 \mathrm{~b}$ \\
\hline & HP & $69308 b$ & $6451 b$ & $11.9 \mathrm{~b}$ & $1.07 \mathrm{~b}$ \\
\hline & $\mathbf{T P}$ & $76685 a$ & $7369 a$ & $13.1 \mathrm{a}$ & $1.21 \mathrm{a}$ \\
\hline \multirow{2}{*}{ Cultivar } & S.C.260 & $65481 a$ & $6786 a$ & $11.2 \mathrm{a}$ & $1.13 \mathrm{a}$ \\
\hline & S.C.704 & $76342 a$ & $6553 a$ & $13.1 \mathrm{a}$ & $1.07 \mathrm{a}$ \\
\hline
\end{tabular}

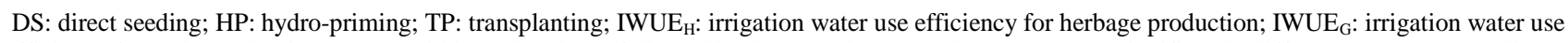
efficiency for grain production. Means within each column followed by the same lowercase letter(s) are not significantly different ( $\mathrm{P} \leq 0.05)$ according to Duncan's multiple range test

Plant growth rate depends on light absorption and the efficiency of converting this light into dry matter. The increase in the HY on PD1 can be explained by plants' more efficient use of sunlight at the beginning of the planting season (Aziz et al. 2007). 
On the other hand, the delayed cultivation of maize reduces its photosynthetic activities due to its sensitivity to lower temperatures. These results are consistent with those of other studies and suggest that HY was affected by photoperiod, and delayed cultivation resulted in shorter plants with fewer and smaller leaves through shortening of photoperiod (Srivastava et al. 2018; Cao et al. 2019).

The herbage yield was significantly affected by the planting method and cultivar (Table 5). The Highest and lowest herbage yield was produced from TP of S.C.704 (80490 kg ha-1) and DS of S.C.260 (60582 kg ha-1), respectively (Figure 1a). In line with our findings, Andonova et al. (2014) observed that transplanted plants increased maize biomass accumulation compared to the direct-seeded ones. The mechanisms associated with increased yield in transplanted plants are improving light interception, leaf area development, and changes in anatomical features such as the phloem to xylem ratio and the vascular bundle to mesophyll ratio related to TP (Aziz et al. 2007).
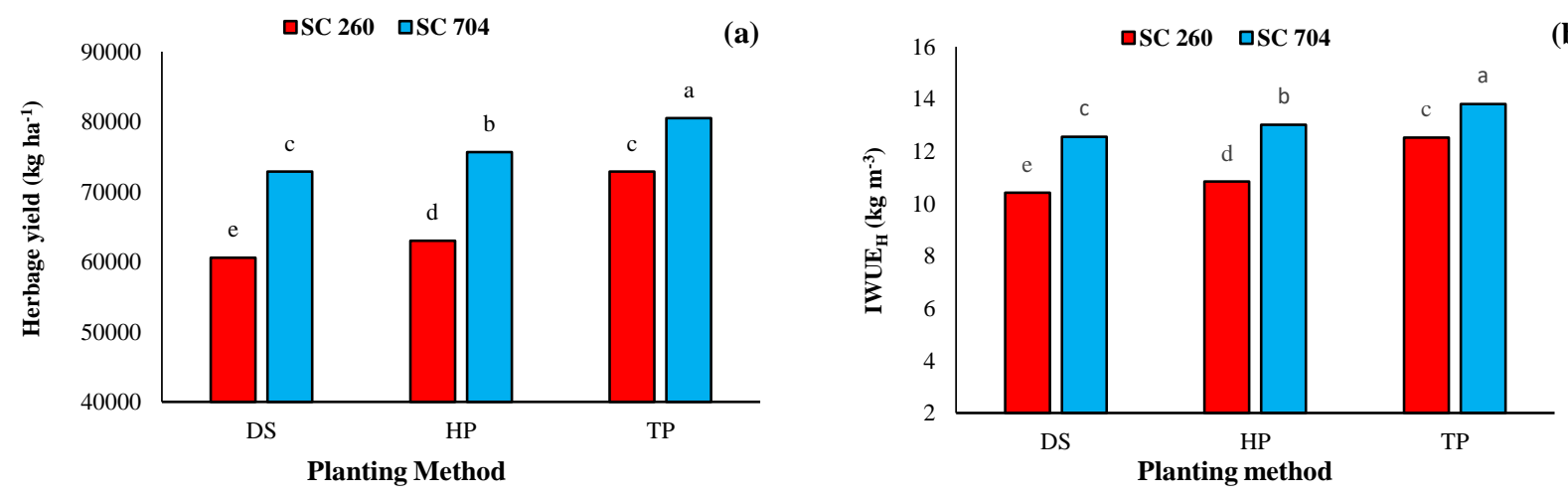

Figure 1- The effect of planting method $\times$ cultivar on the herbage yield (a), and irrigation water use efficiency for herbage production (b) DS, direct seeding; HP, seed hydro-priming; TP, transplanting; IWUE $\mathrm{H}_{\mathrm{H}}$, irrigation water use efficiency for herbage production.

On the other hand, based on our results, the S.C.704 as a late-maturing cultivar showed greater herbage yield than the S.C.260 as an early-maturing cultivar in all planting methods (Figure 1a). These results corroborate with other authors, who mention that the herbage yield is influenced by genotype. In comparing cultivars, the herbage yield of late-maturing significantly was higher than early-maturing ones. Late maturing cultivars took more days to maturity and hence had a better chance to utilize more nutrients and more photosynthetic activity, resulting in higher herbage yield (Aziz et al. 2007; Hassan et al. 2020a).

\subsection{Irrigation water use efficiency for herbage production}

Water deficit is one of the main limiting factors in maize production in different regions of the world. Due to declining irrigation sources, improvement of IWUE of crops becomes more essential nowadays. IWUE depends on several factors, including genotype, planting time, and method of planting.

The IWUE $\mathrm{H}_{\mathrm{H}}$ was significantly affected by planting date, as shown in Table 5. Based on the result of this study, the highest

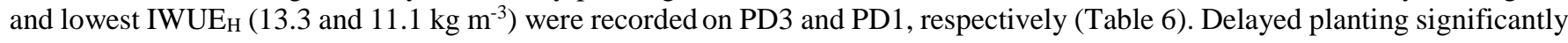

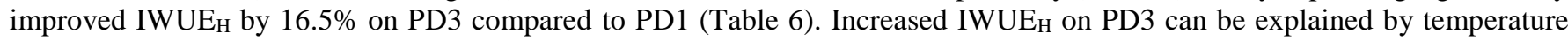
decreases, therefore, reduces evaporation in delayed cultivation. The present findings seem consistent with other research, which found a significant increase in $\mathrm{IWUE}_{\mathrm{H}}$ in the delayed planting of maize (Feyzbakhsh et al. 2015).

IWUE $_{\mathrm{H}}$ was also remarkably influenced by the planting method and cultivar interaction, and the highest and lowest IWUE $\mathrm{H}_{\mathrm{H}}$ (13.806 and $10.415 \mathrm{~kg} \mathrm{~m}^{-3}$ ) was obtained from transplanting S.C.704 and direct seeding of S.C.260 (Figure 1b). Compared with S.C.260, the late-maturing variety (S.C.704) significantly extended the maize growing cycle, increasing the HY and the IWUE in all three PMs (Bu et al. 2015). Since various cultivars of crops have different IWUE, recognizing and cultivation cultivars with higher IWUE could improve the water productivity per unit area. In line with our finding, Rafiee \& Kalhor (2016) reported that the late-maturing hybrids such as S.C.704 had a higher IWUE than mid-maturing hybrids. On the other hand, the transplanted maize used available water most efficiently. In previous research, TP of maize increased the IWUE by $66 \%$ or more over the DS (San Miguel-Chávez \& Larqué Saavedra 1996). Overall, choosing appropriate maize hybrids and a suitable planting method will contribute to the effective use of agricultural water resources.

\subsection{Grain yield}

The GY was significantly affected by the interaction of planting date and planting method (Table 5). Results revealed that the maximum GY (9655 kg ha $\left.{ }^{-1}\right)$ was obtained from TP on PD1 and the minimum GY (2646 kg ha-1) obtained from DS on PD3 (Figure 2a). According to the findings, delayed planting using any of the three PMs (DS, HP, and TP) significantly reduced the 
GY (Figure 2a). The current experiment results also presented the superiority of TP over HP and DS to achieve higher GY. The TP obtained more GY than HP by $11.3 \%, 12.5 \%$ and $16.5 \%$ on PD1, PD2 and PD3, respectively (Figure 2a). Comparison of HP and DS on PD3 indicated that hydro-priming with $18.8 \%$ more grain yield was a better planting method than direct seeding.
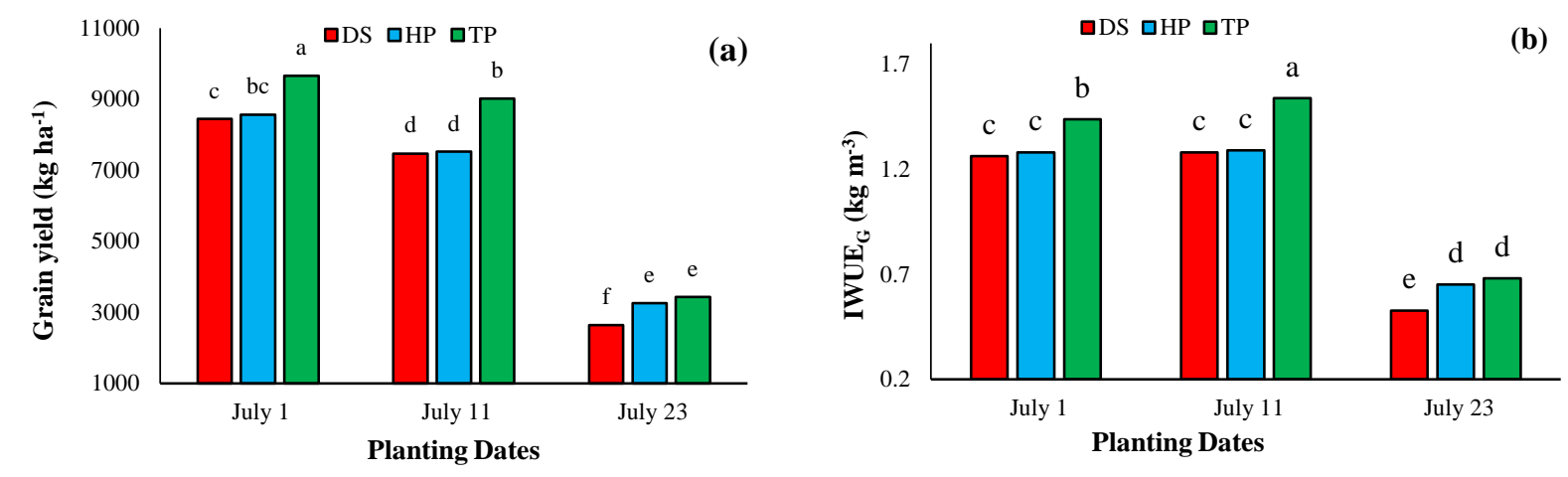

Figure 2- Effect of planting date $\times$ planting method on the grain yield (a), and IWUEG (b) DS, direct seedling; HP, seed hydropriming; TP, transplanting; $\mathrm{IWUE}_{\mathrm{G}}$, irrigation water use efficiency for grain production.

Our results align with previous studies, which also reported that delayed cultivation had reduced the grain yield (Feyzbakhsh et al. 2015; Cao et al. 2019). The decrease in grain yield of delayed planting crops could be attributed to lower nutrient uptake and reduced photosynthetic translocation in the developing seeds. Srivastava et al. (2018) concluded that delayed planting reduced overall growth stage duration from 143 days in regular cultivation to 127 days in delayed cultivation, resulting in lower grain yield.

The data revealed that transplanting maize as a strategy for crop management increased grain yield by shortening the growth period. These results match those observed in the earlier study, in which the growth period of maize had cultivated using TP was shorter than DS in a way that it reached flowering 11-15 days earlier (Fanadzo et al. 2009). Despite the higher GY of TP than HP on PD3, this difference was not significant. During manual uprooting of seedlings to the main field on PD3, breaking some of the seminal roots had coincided with high temperature, and transplanting shock got worse. This might result in the inability of maize roots to regenerate after TP and GY reduction (Andonova et al. 2014).

Moreover, GY is highly affected by the interaction of Year $\times \mathrm{PD} \times \mathrm{CV}$ (Table 5). The highest GY in 2017 and 2018 (9193 kg $\mathrm{ha}^{-1}$ and $9609 \mathrm{~kg} \mathrm{ha}^{-1}$, respectively) was obtained from S.C.704 on PD1. Further, the lowest GY in 2017 (2604 kg ha $\left.{ }^{-1}\right)$ and 2018 $\left(2104 \mathrm{~kg} \mathrm{ha}^{-1}\right.$ ) were achieved from S.C.704 on PD3 (Figure 3a). As planting was delayed from 1 to 11 July, the GDD decreased by 169.4 and 180.8 in 2017 and 2018, respectively. This GDD reduction decreased the grain yield of S.C.704 by about $8 \%$ and $24 \%$ in two consecutive years; however, the grain yield of S.C.260 wasn't affected (Figure 3a, Table 4). In addition, we found a $70 \%$ (2017) and 71\% (2018) reduction in GY of S.C.704 when planting was delayed from 1 to 23 July. However, the GY of S.C. 260 was reduced by $48 \%$ (2017) and $60 \%$ (2018) when planting was delayed 3 weeks in two consecutive years. It means that two hybrids responded differently to delayed planting and available GDD since the GDD on PD3 was about 345.2 and 384.7 fewer than 1 July in 2017 and 2018, respectively (Figure 3a, Table 4).
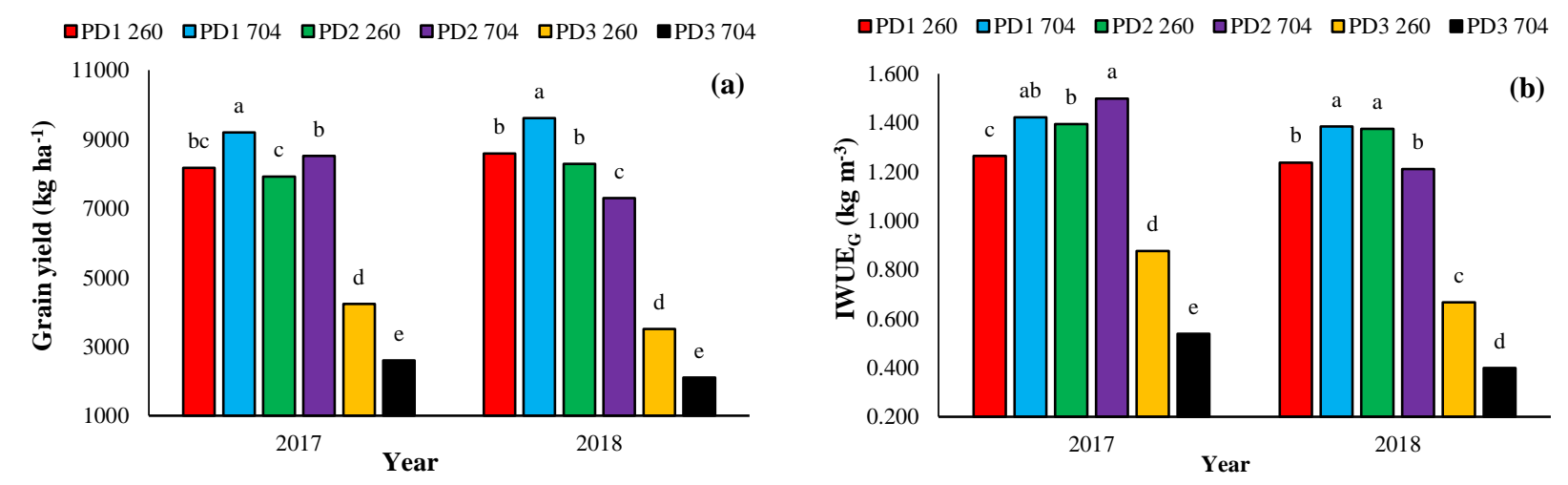

Figure 3- Effect of year $\times$ planting date $\times$ cultivar on the grain yield (a), and IWUE $(b)$ sliced on year

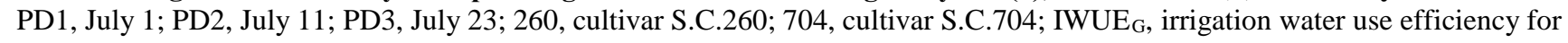
grain production.

Each maize cultivar has its optimal planting date; according to the results, S.C.704 obtained significantly higher GY on PD1 than S.C.260 in both years. The late-maturing varieties of maize resulted in higher GY if cultivated on optimized PD since these 
varieties genetically require more time for the grain-filling period and could obtain more water resources for plant growth and grain production (Rafiee \& Kalhor 2016). However, as planting was delayed, the GY of S.C.704 affected more negatively than S.C.260 in both years since S.C.260 (early-maturing) obtained required GDD in a shorter duration compared to S.C.704 (latematuring). Moreover, despite late-maturing cultivars' potential to produce high yields when planted on a suitable date, delayed planting causes them to enter into the flowering phase earlier due to their low growth rate (Hassan et al. 2020b). We found that S.C.260 is superior in GY to S.C.704 in delayed cultivation. In line with our findings, Biswas (2015) and Koca and Canavar (2014) reported that various cultivars of maize in different PD had different amounts of GY.

Furthermore, there was a significant difference in GY of S.C.704 on PD2 (11 July) between two years, which was likely related to the $10 \%$ drop in temperature at the end of the growing season in 2018 compared to 2017 (Table 1), which coincided with the grain maturity and grain-filling period of S.C.704 and subsequently reduced GY on PD2 in 2018 (Figure 3a).

\subsection{Irrigation water use efficiency for grain production}

The effects of PD $\times P M$ on IWUE $_{G}$ were significant (Table 5). The highest $\operatorname{IWUE}_{\mathrm{G}}\left(1.53 \mathrm{~kg} \mathrm{~m}^{-3}\right)$ was recorded from TP on PD2, and the lowest IWUE $\left(0.52 \mathrm{~kg} \mathrm{~m}^{-3}\right)$ was obtained from DS on PD3 (Figure 2b). These results also revealed that delayed cultivation from PD2 to PD3 caused reductions of $\mathrm{IWUE}_{\mathrm{G}} 60 \%, 50 \%$, and $56 \%$, respectively, in DS, HP, and TP. Since there is a direct association between GY and $\mathrm{IWUE}_{\mathrm{G}}$, decreasing the GY in delayed planting led to a remarkable reduction of IWUE $\mathrm{G}_{\mathrm{G}}$ PD3 in all three planting methods.

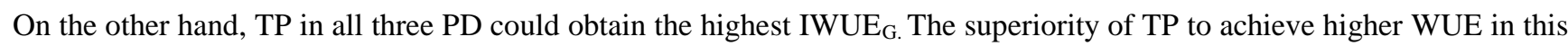
study was mainly due to the shorter growth stage period, about 10-12 days, compared to HP and DS, which decreased the requirement for irrigation at least $700 \mathrm{~m}^{3}$ in this study. In line with the present study, investigating the effects of TP on cotton and maize showed that TP could lead to an increase in IWUE (Biswas 2015).

Examining the effects of Year $\times \mathrm{PD} \times \mathrm{CV}$ interactions on $\mathrm{IWUE}_{\mathrm{G}}$ showed that the highest $\operatorname{IWUE}_{\mathrm{G}}\left(1.49 \mathrm{~kg} \mathrm{~m}^{-3}\right) \mathrm{was}^{\mathrm{obtained}}$ from cultivating S.C.704 on PD2 in 2017, and the lowest $\operatorname{IWUE}_{\mathrm{G}}\left(0.39 \mathrm{~kg} \mathrm{~m}^{-3}\right)$ was obtained from S.C.704 on PD3 in 2018 (Figure 3b). IWUE I $_{\mathrm{G}}$ of cultivars in all planting dates decreased in 2018 compared to 2017 since the higher temperature in 2018

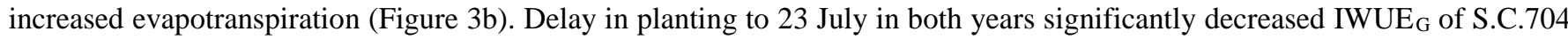
and S.C.260. The reduction of IWUE $_{\mathrm{G}}$ under delayed planting was due to a higher reduction in maize GY than the consumptive water use (Bu et al. 2015).

On the other hand, IWUE ${ }_{G}$ of S.C.260 significantly increased about $10 \%$ as cultivation was delayed from 1 to 11 July in both years (Figure 3b). A possible explanation for these results may be the insignificant differences in GY of S.C.260 when planting was delayed for 10 days (Figure 3a), besides less evapotranspiration occurred on PD2 rather than PD1, which led to enhancement of IWUE ${ }_{\mathrm{G}}$. In comparing hybrids, S.C.260 in delayed planting dates resulted in better IWUE $\mathrm{G}_{\mathrm{G}}$ in both years. This result agrees with the findings of other studies, which reported that the WUE of maize depends on multiple factors, such as genotype. The shorter growing period in early-maturing cultivars like S.C.260 than late-maturing ones may lead to lower evapotranspiration,

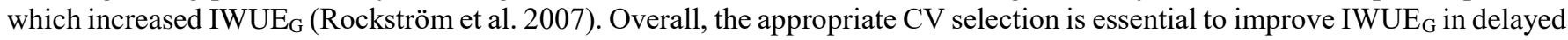
planting.

\subsection{Grain quality}

Maize is an important crop, and concerns about grain quality are increasingly important. According to the findings of the present study, grain quality parameters were significantly affected by sowing date (Table 7). As shown in Table 8, delayed planting negatively affects qualitative traits of grain maize such as CP, DDM, starch, and WSC. The highest CP, DDM, starch, WSC were obtained on PD1, and the lowest contents were obtained on PD3. Delaying cultivation from PD1 to PD3 decreased CP, DDM, starch and WSC by $11.5 \%, 11 \%, 8 \%$ and 13\%, respectively (Table 8 ). 
Table 7- P-Values obtained from ANOVA for the effect of planting date (July 1, July 11, and July 23), planting method (hydro-priming, transplanting, and direct seeding) and cultivar (late-maturing S.C. 704 and early-maturing S.C.260) on grain quality of maize

\begin{tabular}{lllllllll}
\hline Source of variation & $\boldsymbol{d} \boldsymbol{f}$ & $\boldsymbol{C P}$ & $\boldsymbol{D D M}$ & Starch & $\boldsymbol{A s h}$ & $\boldsymbol{C F}$ & WSC & Oil \\
\hline Year $(\mathbf{Y})$ & 1 & 0.8953 & 0.5056 & 0.324 & 0.6855 & 0.6412 & 0.7718 & 0.8994 \\
$\mathbf{R e p}(\mathbf{Y}$ ear) & 4 & 0.0220 & 0.0960 & 0.2172 & 0.3475 & 0.7471 & 0.8101 & 0.1849 \\
$\mathbf{P l a n t i n g}$ Date $(\mathbf{P D})$ & 2 & 0.0500 & 0.0311 & 0.0153 & 0.0006 & 0.0290 & 0.0444 & 0.1114 \\
$\mathbf{Y} \times \mathbf{P D}$ & 2 & 0.8999 & 0.5870 & 0.4223 & 0.9155 & 0.1683 & 0.7395 & 0.2345 \\
$\mathbf{R e p}(\mathbf{Y} \times \mathbf{P D})$ & 8 & 0.6368 & 0.8559 & 0.6711 & 0.1098 & 0.2984 & 0.2452 & 0.2597 \\
$\mathbf{P l a n t i n g}$ Method $(\mathbf{P M})$ & 2 & 0.0405 & 0.8900 & 0.0227 & 0.0281 & 0.0046 & 0.8813 & 0.0500 \\
$\mathbf{P D} \times \mathbf{P M}$ & 4 & 0.0879 & 0.2762 & 0.7511 & 0.0243 & 0.0184 & 0.6477 & 0.2102 \\
$\mathbf{Y} \times \mathbf{P M}$ & 2 & 0.7287 & 0.8196 & 0.7708 & 0.5495 & 0.9783 & 0.1379 & 0.646 \\
$\mathbf{Y} \times \mathbf{P D} \times \mathbf{P M}$ & 4 & 0.5261 & 0.5358 & 0.1769 & 0.0618 & 0.9140 & 0.1066 & 0.5342 \\
$\mathbf{C u l t i v a r}(\mathbf{C V})$ & 1 & 0.1411 & 0.1958 & 0.9028 & 0.0277 & 0.0891 & 0.7247 & 0.2966 \\
$\mathbf{Y} \times \mathbf{C V}$ & 1 & 0.2324 & 0.9485 & 0.1961 & 0.7083 & 0.7744 & 0.5981 & 0.5766 \\
$\mathbf{P D} \times \mathbf{C V}$ & 2 & 0.5780 & 0.3245 & 0.4409 & 0.0013 & 0.0068 & 0.1678 & 0.1894 \\
$\mathbf{Y} \times \mathbf{P D} \times \mathbf{C V}$ & 2 & 0.2323 & 0.3706 & 0.1434 & 0.6866 & 0.9136 & 0.2575 & 0.5014 \\
$\mathbf{P M} \times \mathbf{C V}$ & 2 & 0.4090 & 0.2284 & 0.9036 & 0.0883 & 0.7547 & 0.1628 & 0.3779 \\
$\mathbf{Y} \times \mathbf{P M} \times \mathbf{C V}$ & 2 & 0.1270 & 0.7774 & 0.5438 & 0.1963 & 0.2572 & 0.9536 & 0.5627 \\
$\mathbf{P D} \times \mathbf{P M} \times \mathbf{C V}$ & 4 & 0.4921 & 0.3587 & 0.5389 & 0.0134 & 0.7898 & 0.218 & 0.6734 \\
$\mathbf{Y} \times \mathbf{P D} \times \mathbf{P M} \times \mathbf{C V}$ & 4 & 0.9647 & 0.2119 & 0.4745 & 0.9980 & 0.7710 & 0.8939 & 0.6040 \\
\hline
\end{tabular}

df: degree of freedom; CP: crude protein; DDM: digestible dry matter; CF: crude fiber; WSC: water-soluble carbohydrate

Table 8- The effect of year, planting date, planting method and cultivar on grain quality of maize

\begin{tabular}{|c|c|c|c|c|c|c|c|c|}
\hline \multicolumn{2}{|c|}{ Experimental Factors } & $C P$ & $D D M$ & Starch & Ash & $C F$ & WSC & Oil \\
\hline & & \multicolumn{7}{|l|}{$\%$} \\
\hline \multirow{2}{*}{ Year } & 2017 & $8.87 \mathrm{a}$ & $82.08 \mathrm{a}$ & $68.5 \mathrm{a}$ & $1.40 \mathrm{a}$ & $2.92 \mathrm{a}$ & $3.59 \mathrm{a}$ & $3.71 \mathrm{a}$ \\
\hline & 2018 & $10.51 \mathrm{a}$ & $80.81 \mathrm{a}$ & $69.7 \mathrm{a}$ & $1.38 \mathrm{a}$ & $2.90 \mathrm{a}$ & $3.65 \mathrm{a}$ & $3.70 \mathrm{a}$ \\
\hline \multirow{3}{*}{$\begin{array}{l}\text { Planting } \\
\text { Date }\end{array}$} & July01 & $9.86 a$ & $86.5 \mathrm{a}$ & $71.5 \mathrm{a}$ & $1.63 \mathrm{a}$ & $3.23 \mathrm{a}$ & $3.90 \mathrm{a}$ & $3.89 \mathrm{a}$ \\
\hline & July11 & $9.26 \mathrm{ab}$ & $80.6 \mathrm{~b}$ & $70.0 \mathrm{a}$ & $1.60 \mathrm{~b}$ & $3.11 \mathrm{a}$ & $3.58 \mathrm{ab}$ & $3.69 \mathrm{a}$ \\
\hline & July23 & $8.72 b$ & $77.3 b$ & $65.9 \mathrm{~b}$ & $1.34 \mathrm{c}$ & $2.77 \mathrm{~b}$ & $3.40 \mathrm{~b}$ & $3.53 \mathrm{a}$ \\
\hline \multirow{3}{*}{$\begin{array}{l}\text { Planting } \\
\text { Method }\end{array}$} & DS & $9.30 \mathrm{ab}$ & $81.6 \mathrm{a}$ & $69.5 \mathrm{a}$ & $1.51 \mathrm{~b}$ & $3.04 \mathrm{~b}$ & $3.57 \mathrm{a}$ & $3.74 \mathrm{a}$ \\
\hline & HP & $9.48 \mathrm{a}$ & $81.7 \mathrm{a}$ & $69.6 \mathrm{a}$ & $1.56 \mathrm{a}$ & $3.09 \mathrm{a}$ & $3.68 \mathrm{a}$ & $3.75 \mathrm{a}$ \\
\hline & $\mathbf{T P}$ & $9.06 \mathrm{~b}$ & $80.9 \mathrm{a}$ & $68.1 \mathrm{~b}$ & $1.51 \mathrm{~b}$ & $2.99 \mathrm{c}$ & $3.62 \mathrm{a}$ & $3.61 \mathrm{~b}$ \\
\hline \multirow{2}{*}{ Cultivar } & S.C.260 & $8.95 \mathrm{a}$ & $81.3 \mathrm{a}$ & $69.2 \mathrm{a}$ & $1.50 \mathrm{~b}$ & $3.00 \mathrm{a}$ & $3.61 \mathrm{a}$ & $3.74 \mathrm{a}$ \\
\hline & S.C.704 & $9.61 \mathrm{a}$ & $81.6 a$ & $69.1 \mathrm{a}$ & $1.55 \mathrm{a}$ & $3.08 \mathrm{a}$ & $3.63 \mathrm{a}$ & $3.67 \mathrm{a}$ \\
\hline
\end{tabular}

DS, direct seeding; HP, hydro-priming; TP, transplanting; CP, crude protein; DDM, digestible dry matter; CF, crude fiber; WSC, water-soluble carbohydrate.

Means within each column followed by the same lowercase letter(s) are not significantly different $(\mathrm{P} \leq 0.05)$ according to Duncan's multiple range test.

Maize grains mainly consist of endosperm and embryo, containing protein, starch, oil, and other grain quality parameters (Motto et al. 2012). As we explained later, delayed planting could disrupt maize grain growth and development, reducing grain quality. In accordance with the present results, previous studies have demonstrated that delayed sowing of maize negatively affects the grain quality since there is a high probability of experiencing lower temperature during the grain-filling period and reduction of rate and duration of grain filling in delayed cultivation (Koca and Canavar. 2014; Cao et al. 2019). Grain nutritional contents reduction in delayed sowing supports the idea of down-regulation of enzymatic activities in delayed planting dates, which results in lower assimilate convention and grain starch, oil, and protein reduction.

Based on our findings, the effect of the planting method on some qualitative traits such as CP, starch, and oil was significant. The hydro-priming method had the highest CP, starch, and oil (9.48, 69.6, and 3.75\%, respectively). The lowest contents of CP, starch, and oil were obtained from transplanted maize (Table 8). According to the results, HP was found to be the optimal PM to enhance grain quality. Furthermore, assessing the interactions of $\mathrm{PD} \times \mathrm{PM}$ on the $\mathrm{CF}$ (Table 7) indicated that the highest $\mathrm{CF}$ $(3.27 \%)$ was obtained from HP on 1 July and the lowest CF (2.65\%) obtained from TP on 23 July (Figure 4a). Delayed planting 
from PD1 to PD2 decreased CF by $2.8 \%, 3.4 \%$, and $4.9 \%$ in DS, HP, TP, respectively. Likewise, CF content was reduced when planting delayed from PD1 to PD3 in DS (11.6\%), HP (13.1\%), and TP (18.2\%). As shown in Figure 4a, CF obtained from TP is more negatively affected by delayed sowing than the other two planting methods. As mentioned in the previous literature review, the maize grain quality could be remarkably affected by planting method and date (Mason \& D'croz-Mason 2002). Seed priming of maize could affect grain quality through various physiological strategies and improve grain quality under different PD. Indeed, seed priming triggers a range of biochemical reactions and enhances photoassimilates translocation (Bakhtavar et al. 2015).
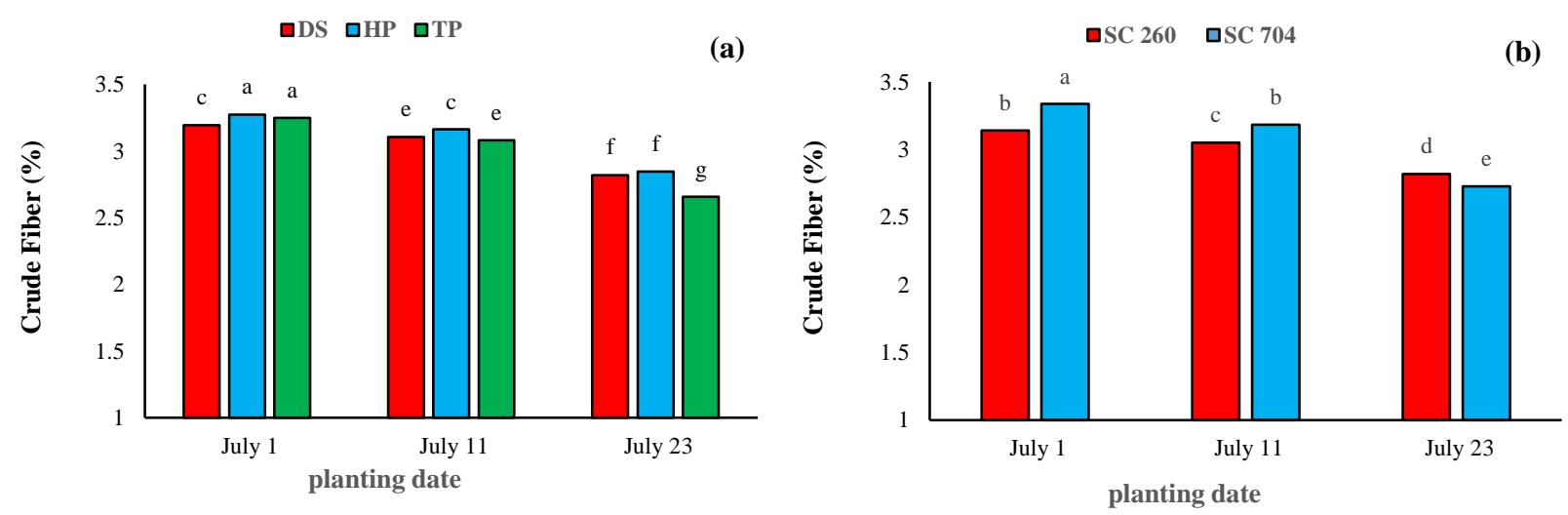

Figure 4- Effect of planting date $\times$ planting method (a), and planting date $\times$ cultivar (b) on crude fiber content DS, direct seedling; HP, seed hydro-priming; TP, transplanting; 260, S.C.260; 704, S.C.704.

The $\mathrm{CF}$ is one of the main parameters influencing the quality of maize. Based on the findings, the interactions of $\mathrm{PD} \times \mathrm{CV}$ on CF were significant (Table 7). The highest and lowest CF were obtained from S.C.704 on PD1 and PD3, respectively. Our findings revealed that CF of S.C.704 and S.C.260 decreased by $18.3 \%$ and $10.2 \%$ in delayed sowing from 1 to 23 July, respectively. Variation in grain quality parameters among different hybrids in delayed planting is in line with Buriro et al. (2015), who reported that grain quality parameters such as protein, starch, and oil content were significantly affected by genetic differences among maize cultivars and different sowing dates.

In addition, the interaction of $\mathrm{PD} \times \mathrm{PM} \times \mathrm{CV}$ on ash was significant (Table 7). In this study, transplanted S.C.704 on PD1 had maximum ash content (1.71\%) whereas, from transplanting variety S.C.704 on PD3 minimum ash (1.26\%) was obtained (Figure 5). Comparing three PD revealed that the lowest ash content of all CV and PM was achieved on PD3. The highest ash content on PD3 (1.42\%), obtained from hydro-priming S.C.260.

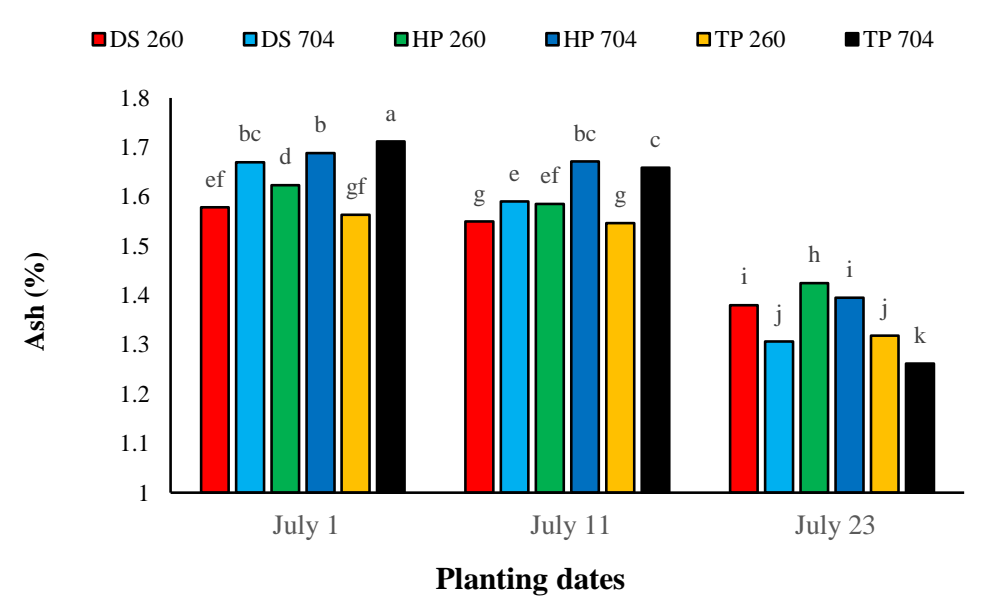

Figure 5- Effect of planting date $\times$ planting method $\times$ cultivar on ash content DS, direct seedling; HP, seed hydro-priming; TP, transplanting; 260, S.C..260; 704, S.C.704 


\section{Conclusions}

To our knowledge, this is the first report of the effect of transplanting and hydro-priming on grain yield, herbage yield, irrigation water use efficiency, and grain quality of late- and early-maturing maize cultivars under delayed planting. It was concluded from the findings of the present research that all quantity and quality traits of grain maize except IWHE $_{\mathrm{H}}$ remarkably decreased in delayed planting. Most agronomic and qualitative characteristics were significantly affected by the planting date, planting method, and cultivar interactions. Our data revealed the superiority of transplanting to achieve high grain and herbage yield among other planting methods. On the other hand, hydro-priming was the optimal planting method to enhance grain quality in delayed planting. Furthermore, selecting S.C.260 as a suitable hybrid on delayed planting is suggested. Choosing an appropriate planting method and cultivar could help farmers achieve a higher maize GY, HY, IWUE in delayed planting. Further investigations are necessary to validate the kinds of conclusions that can be drawn from this study.

\section{Acknowledgments}

This research was a part of PhD thesis of the first author and funded and supported by Seed and Plant Improvement Institute, Agricultural Research, Education and Extension Organization (AREEO), Karaj, Iran. (Project No: 0-03-03-012- 960188).

\section{Abbreviations}

PD, planting date; PD1: July $1^{\text {st. }}$ PD2: July $11^{\text {th}}$; PD3: July $23^{\text {rd }}$; PM, planting method; TP, transplanting; HP, hydro-priming; DS, direct seeding; CV, cultivar; GY, grain yield; HY, herbage yield, IWUE, irrigation water use efficiency; IWUEG, IWUE for grain production; IWUE $\mathrm{H}_{\mathrm{H}}$, IWUE for herbage production; $\mathrm{CP}$, crude protein; $\mathrm{CF}$, crude fiber; DDM, digestible dry matter; WSC: water-soluble carbohydrate.

\section{References}

Allen R G, Pereira L P, Raes D \& Smith M (1998). Crop evapotranspiration-Guidelines for computing crop water requirements- FAO Irrigation and drainage paper 56. FAO, Rome 300(9): D05109

Andonova P S, Rattin J \& Di Benedetto A (2014). Yield increase as influenced by transplanting of sweet maize (Zea mays L. saccharata). Journal of Experimental Agriculture International 4(11): 1314-1329 DOI: 10.9734/AJEA/2014/11077

Aziz A, Rehman H U \& Khan N (2007). Maize cultivar response to population density and planting date for grain and biomass yield. Sarhad Journal of Agriculture 23(1): 25-30

Baghdadi A, Balazadeh M, Kashani A, Golzardi F, Gholamhoseini M \& Mehrnia M (2017). Effect of pre-sowing and nitrogen application on forage quality of silage corn. Agronomy Research 15(1): 11-23

Bakhtavar M A, Afzal I, Basra S M, Ahmad A U \& Noor M A (2015). Physiological strategies to improve the performance of spring maize (Zea mays L.) planted under early and optimum sowing conditions. PloS one 10(4): e0124441 DOI: 10.1371/journal.pone.0124441

Bartlett M S (1937). Properties of sufficiency and statistical tests. Proceedings of the Royal Society of London. Series A-Mathematical and Physical Sciences 160(901): 268-282 DOI: 10.1098/rspa.1937.0109

Biswas M (2015). Direct seeded and transplanted maize: Effects of planting date and age of seedling on the yield and yield attributes. Journal of Experimental Agriculture International 5(5): 489-497 DOI: 10.9734/AJEA/2015/13594

Bu L, Chen X, Li S, Liu J, Zhu L, Luo S, Hill RL \& Zhao Y (2015). The effect of adapting cultivars on the water use efficiency of dryland maize (Zea mays L.) in northwestern China. Agricultural Water Management 148: 1-9 DOI: 10.1016/j.agwat.2014.09.010

Buriro M, Bhutto T, Gandahi A, Kumbhar I \& Shar M (2015). Effect of sowing dates on growth, yield and grain quality of hybrid maize. Journal of Basic and Applied Sciences 11: 553-558 DOI: 10.6000/1927-5129.2015.11.73

Cao Q, Li G, Yang F, Jiang X, Diallo L, Zhang E \& Kong F (2019). Maize yield, biomass and grain quality traits responses to delayed sowing date and genotypes in rain-fed condition. Emirates Journal of Food and Agriculture 27: 415-425 DOI: 10.9755/ejfa.2019.v31.i6.1969

Fanadzo M, Chiduza C \& Mnkeni P N S (2009). Comparative response of direct seeded and transplanted maize (Zea mays L.) to nitrogen fertilization at Zanyokwe irrigation scheme, Eastern Cape, South Africa. African Journal of Agricultural Research 4(8): 689-694 DOI: 10.5897/AJAR.9000116

FAO (2019). Crops and livestock products. Retrived in Junuary, 1, 2021 from http://www.fao.org/faostat/en/\#data/TP

Feyzbakhsh M T, Kamkar B, Mokhtarpour H \& Asadi M E (2015). Effect of soil water management and different sowing dates on maize yield and water use efficiency under drip irrigation system. Archives of Agronomy and Soil Science 61(11): 1581-1592 DOI: $10.1080 / 03650340.2015 .1019345$

Golzardi F, Baghdadi A \& Afshar R K (2017). Alternate furrow irrigation affects yield and water-use efficiency of maize under deficit irrigation. Crop and Pasture Science 68(8): 726-734

Hassan M U, Chattha M U, Barbanti L, Mahmood A, Chattha M B, Khan I, Mirza S, Aziz S A, Nawaz M \& Aamer M (2020a). Cultivar and seeding time role in sorghum to optimize biomass and methane yield under warm dry climate. Industrial Crops and Products 145: 111983 DOI: $10.1016 /$ j.indcrop.2019.111983

Hassan M U, Chattha M U, Khan I, Chattha M B, Barbanti L, Aamer M, Iqbal M M, Nawaz M, Mahmood A, Ali A \& Aslam M T (2020b). Heat stress in cultivated plants: nature, impact, mechanisms, and mitigation strategies-a review. Plant Biosystems-An International Journal Dealing with all Aspects of Plant Biology 155(2): 211-234 DOI: 10.1080/11263504.2020.1727987

Khalily M, Moghaddam M, Kanouni H \& Asheri E (2010). Dissection of drought stress as a grain production constraint of maize in Iran. Asian Journal of Crop Science 2(2): 60-69 DOI: 10.3923/ajcs.2010.60.69

Koca Y \& Canavar O (2014). The effect of sowing date on yield and yield components and seed quality of corn (Zea mays L.). Sci Papers Series A Agron 57: 227-223 
Long N V, Assefa Y, Schwalbert R, Ciampitti I A (2017). Maize yield and planting date relationship: A synthesis-analysis for US high-yielding contest-winner and field research data. Frontiers in Plant Science 8: 2106 DOI: 10.3389/fpls.2017.02106

Loy D D \& Lundy E L (2019). Nutritional properties and feeding value of corn and its coproducts. In: Corn (Elsevier) AACC International Press, pp. 633-659 DOI: 10.1016/B978-0-12-811971-6.00023-1.

Mason S C \& D'croz-Mason N E (2002). Agronomic practices influence maize grain quality. Journal of Crop Production 5(1-2): 75-91 DOI: 10.1300/J144v05n01_04

McMaster G S \& Wilhelm W W (1997). Growing degree-days: one equation, two interpretations. Agric. Forest Meteorol 87: 291-300 DOI: 10.1016/ s0168-1923(97)00027-0

Moradi R, Koocheki A, Mahallati M N \& Mansoori H (2013). Adaptation strategies for maize cultivation under climate change in Iran: irrigation and planting date management. Mitigation and Adaptation Strategies for Global Change 18(2): 265 284 DOI: $10.1007 / \mathrm{s} 11027-$ 012-9410-6.

Motto M, Hartings H, Fracassetti M \& Consonni G (2012). Grain quality-related traits in maize: gene identification and exploitation, Maydica 56(3): 291-314.

Nazari S, Aboutalebian M A \& Golzardi F (2017). Seed priming improves seedling emergence time, root characteristics and yield of canola in the conditions of late sowing. Agronomy Research 15(2): 501-514

Rafiee M \& Kalhor M (2016). Economic water use efficiency of corn (Zea mays L.) hybrids as affected by irrigation regimes: a case study in West Iran. Archives of Agronomy and Soil Science 62(6), 781-789 DOI: 10.1080/03650340.2015.1105360

Rashid A, Hollington P A, Harris D \& Khan P (2006). On-farm seed priming for barley on normal, saline and saline-sodic soils in North West Frontier Province, Pakistan. European journal of agronomy 24(3): 276-281 DOI: 10.1016/j.eja.2005.10.006

Rockström J, Lannerstad M \& Falkenmark M (2007). Assessing the water challenge of a new green revolution in developing countries. Proceedings of the National Academy of Sciences 104(15): 6253-6260 DOI: 10.1073/pnas.0605739104

San Miguel-Chávez R \& Larqué Saavedra A L (1996). Increased water use efficiency and grain yield by transplanting maize, Drought-and Low N-Tolerant Maize 25: 179

Siesler H W, Ozaki Y, Kawata S \& Heise H M (Eds.) (2002). Near-infrared spectroscopy: principles, instruments, applications. John Wiley \& Sons, Germany

Srivastava R K, Panda R K, Chakraborty A \& Halder D (2018). Enhancing grain yield, biomass and nitrogen use efficiency of maize by varying sowing dates and nitrogen rate under rainfed and irrigated conditions. Field Crops Research 221: 339-49 DOI: 10.1016/j.fcr.2017.06.019

Ünay A, Sabanci I, Cinar V M (2021). The Effect of Maize (Zea mays L.)/Soybean (Glycine max (L.) Merr.) Intercropping and Biofertilizer (Azotobacter) on Yield, Leaf Area Index and Land Equivalent Ratio. Journal of Agricultural Sciences 27(1): 76-82 DOI: 10.15832/ankutbd.572495

Rehman H, Iqbal H, Basra S M, Afzal I, Farooq M, Wakeel A \& Ning W A (2015). Seed priming improves early seedling vigor, growth and productivity of spring maize. Journal of Integrative Agriculture 14(9): 1745-1754 DOI: 10.1016/S2095-3119(14)61000-5

(C) 2022 by the author(s). Published by Ankara University, Faculty of Agriculture, Ankara, Turkey. This is an Open Access article distributed under the terms and conditions of the Creative Commons Attribution (CC BY) license (http://creativecommons.org/licenses/by/4.0/), which permits unrestricted use, distribution, and reproduction in any medium, provided the original work is properly cited. 